\title{
Comparison between Ceftriaxone with Ceftriaxone and Metronidazole Combination in Maxillofacial Fracture (at KSM Reconstruction and Aesthetic Plastic Surgery, RSUD Dr. Soetomo)
}

\author{
Nyoman Esha Pradnyana* ${ }^{*}$ Lobredia Zarasade Agus Santoso Budi \\ Reconstructive and Aesthetic Plastic Surgery Specialist Doctor Education Program \\ Faculty of Medicine, Airlangga University
}

\begin{abstract}
The purpose of the research is to evaluate infection rate on maxillofacial fracture in Plastic Surgery and Aesthetic at Dr.Soetomo General Hospital Surabaya, Indonesia, from January 2015 to December 2019. The research is an analytic descriptive study with retrospective cohort design. The affordable population were maxillofacial fracture patients with reconstructive treatment who were given therapeutic antibiotics, namely ceftriaxone at a dose of $2 \mathrm{x}$ $1 \mathrm{~g}$ and metronidazole $3 \times 500 \mathrm{mg}$ intravenously. The collected data is then transferred to IBM Statistical Package for Social Sciences (SPSS) 20 software for statistical analysis with non-parametric statistics. Descriptive and analytical data will be presented in a series of texts and tables. A total of 621 patients medical record were obtained with a characteristic distribution based on gender, age, and history of trauma from 2015 to 2019 where total cases of postoperative infection after facial bone fracture reconstruction were 10 patients $(1.61 \%)$, the incidence of infection with a single antibiotic ceftriaxone were 6 patients $(0.97 \%)$ and cases in the administration of combination of antibiotics ceftriaxone, metronidazole were 4 patients $(0.64 \%)$. The incidence of post-operative infection for facial fracture reconstruction given single ceftriaxone antibiotics was higher than that given the combination of ceftriaxone, metronidazole at KSM Reconstructive and Aesthetic Plastic Surgery, Dr. Soetomo General Hospital, Surabaya, Indonesia from 2015 until 2019.
\end{abstract}

Keywords: ceftriaxone-metronidazole, infection, maxillofacial fracture

DOI: $10.7176 / \mathrm{JHMN} / 97-03$

Publication date: January $31^{\text {st }} 2022$

\section{Introduction}

\subsection{Background}

Maxillofacial trauma is the term used when discussing injuries to the facial skull. Sometimes the term craniomaxillofacial is more appropriate because in this type of injury, the anterior wall and floor of the anterior cranial fossa are also affected (Kellman, 2021). Maxillofacial injuries are one of the most common causes of visitation to the emergency department, ranging from fractures to extensive facial damage that require complex treatment (Jose et al., 2016). Accurate reconstruction of the skull is necessary in order to maintain facial aesthetics and also soft tissue care and has an important impact on critical functions such as vision and chewing (Kellman, 2021). The surgical wound itself has a risk of contamination which is divided into several types, namely clean wounds, clean contaminated wounds, contaminated wounds, dirty or infected wounds according to the Centers for Disease Control and Prevention (Azari and Bell, 2016). Open fractures and soft tissue wounds that show no signs of infection are considered contaminated at the time of repair. Traumatic wounds can become infected due to the presence of bacteria or debris from the environment during repair (Hom, 2009). An algorithm for wound debridement, irrigation, and antibiotic prophylaxis should be used as a reference when performing surgical interventions (Azari and Bell, 2016).

\subsection{Literature Review}

Traumatic facial fractures are predominantly caused by accidents worldwide. The incidence of mandibular and maxillary fractures was the highest among other bones, which was $29.85 \%$, followed by zygomatic fractures $27.64 \%$ and nasal fractures $12.66 \%$ (Ghazali, 2007). Data on Reconstructive and Aesthetic Plastic Surgery at Medical Staff Group, Dr. Soetomo General Hospital Surabaya, showed that cases of facial fracture trauma received at the emergency unit were 69 cases in 2018 and 74 cases in 2019

Postoperative wound infection is a health problem that often occurs and involves a complex process. Cases of postoperative infection must be treated properly because wound infection is responsible for a fairly high level of morbidity and mortality (Zabagio and Sharman, 2020). Infection can manifest locally, but if the infection has become progressive, systemic signs such as weakness or fever will appear (Pisculli, Barker and Farrell, 2011). Maxillofacial trauma post-op infection is a problem that has the potential to create serious problems for patients.

Giving antibiotics in post-traumatic facial reconstruction surgery is expected to prevent cases of infection. Dr. Soetomo General Hospital is a type A hospital which is a referral center hospital for East Java Province. Dr. Soetomo General Hospital has various cases of facial fracture reconstruction ranging from simple to complex 
cases. The antibiotic regimen given in the case of post-traumatic facial fracture reconstruction at KSM (Medical Staff Group) Reconstructive and Aesthetic Plastic Surgery, Dr. Soetomo General Hospital, Surabaya, was divided into two, namely the administration of ceftriaxone antibiotics alone or the administration of ceftriaxone and metronidazole, if the type of case of maxillofacial trauma involved intraoral structures. According to a study by Saikat, the combination of a third-generation cephalosporin with metronidazole provided a better antibacterial outcome in maxillofacial trauma infections. These findings combined therapy with ceftriaxone and metronidazole with different mechanisms had a lower effect on the number of postoperative wound infections compared with the use of cefazolin antibiotics or single cephalosporin antibiotics (Saikat, 2016).

The facial area contains skin and mucosa that are rich in bacteria, but do not have large muscle mass. Facial trauma can be widespread and can be life-threatening if it involves the airway. Oral mucosal structures prevent bacterial contamination of deeper facial structures, but deeper trauma increases the risk of infection. Anaerobic bacterial infections and actinomycetes can occur when trauma to the mouth occurs (Bayston et al, 2000). In a study conducted by Heit et al. in 1997 with a total of 90 mandibular fracture patients who were given ceftriaxone prophylaxis $1 \mathrm{~g}$ per day compared to 2 billion units of penicillin, two patients had infections in each group (Andreasen, 2006). Metronidazole is an antibiotic for anaerobic bacteria used with a combination of chloramphenicol antibiotics, ampicillin in brainstem trauma patients (Petersen and Waterman, 2011). Till now, there is no studies about infection rates in post-op patients with maxillofacial trauma which was only received ceftriaxone compared to patients receiving a combination of ceftriaxone and metronidazole at Dr. Soetomo, General Hospital, Surabaya.

\subsection{Research Method}

This study is a retrospective study, using recorded clinical data at Dr. Soetomo General Hospital from 2015 to 2019 through recording patient's data on infection cases after reconstruction of facial fractures.

\subsection{Research Purpose}

This research aims to find out cases of postoperative infection by giving different antibiotic therapy at KSM Reconstructive and Aesthetic Plastic Surgery Dr. Soetomo General Hospital, so that in the future, the basic data obtained can be applied and become a protocol in the administration of antibiotics to maxillofacial patients.

\section{Material and Methods of Research}

This study is a descriptive analytic study with a retrospective cohort design to examine the outcome of wound infection in facial fracture reconstruction surgery. The target population is maxillofacial fracture patients with reconstructive treatment given therapeutic antibiotics. The affordable population were maxillofacial fracture patients with reconstructive treatment who were given therapeutic antibiotics at Dr. Soetomo General Hospital, Surabaya. The research subjects were the affordable population that met the inclusion criteria.

\subsection{Research Time}

This research was conducted in June 2021 by collecting medical records of patients who met the inclusion and exclusion criteria who ever treated at Dr. Soetomo General Hospital, Surabaya, and Department/KSM of Reconstructive and Aesthetic Plastic Surgery, Faculty of Medicine Airlangga University/ Dr. Soetomo General Hospital, Surabaya from 2015 to 2019.

\subsection{Research Material}

The subject of this research is medical record data of surgical wound infection at KSM Reconstructive and Aesthetic Plastic Surgery Dr. Soetomo General Hospital during the period of January 2015 to December 2019.

\subsection{Inclusion Criteria}

1) Physical Maxillofacial examination data at SMF Reconstructive and Aesthetic Plastic Surgery Dr. Soetomo General Hospital, Surabaya from 2015 to 2019 which experienced post-operative infection

2) Reconstructive surgery patients with facial trauma who were given antibiotics ceftriaxone or ceftriaxone and metronidazole at a dose of $2 \times 1 \mathrm{~g}$ ceftriaxone, and 3x500 mg metronidazole intravenously for 5 days.

\subsection{Method of Sampling.}

This study uses secondary data derived from the medical records of Dr. Soetomo General Hospital Surabaya. The information that will be taken is in the form of the patient's gender, age, diagnosis, type of antibiotic used, and the results of post-reconstruction control.

Samples were taken by tracing the medical record data of patients diagnosed with facial bone fractures who suffered a maxillofacial injury and received reconstruction management at Dr. Soetomo General Hospital, Surabaya, from 2015 until 2019. Patients who meet the inclusion criteria will be included in the sample study. 
The data obtained from the medical record was then processed using Microsoft Excel 2013 software, so that it can be analyzed. Several steps in data processing include, editing to check if the data obtained is relevant; coding is done to simplify the software language analysis by converting it into numbers. After that, processing is carried out so that the data that has been entered can be analyzed, and finely is cleaned or cleaning of data entry errors.

\subsection{Data analysis.}

The collected data is then transferred to the IBM Statistical Package for Social Sciences (SPSS) 20 software, to be analyzed with non-parametric statistics. Descriptive and analytical data will be presented in a series of texts and tables.

The patient's data obtained during the study were guaranteed to be confidential by the researcher and has been approved by the ethics committee of Dr. Soetomo General Hospital, Surabaya, Indonesia (0739/108/4/ $\mathrm{V} / 2021)$.

\section{Results And Discussion}

\subsection{Subject Characteristics}

There was a total of 621 patients data distributed characteristically based on gender, age, and history of trauma from 2015 to 2019.

\subsubsection{Gender}

Reconstructive surgery patients with facial trauma injuries by gender during 2015 to 2019 were shown in Table 1

Table 1. Distribution of patients by sex

\begin{tabular}{|l|c|c|c|c|c|c|c|c|c|c|c|c|}
\hline Gender & \multicolumn{2}{|c|}{2015} & \multicolumn{2}{c|}{2016} & \multicolumn{2}{c|}{2017} & \multicolumn{2}{c|}{2018} & \multicolumn{3}{c|}{2019} & $2015-2019$ \\
\hline & $\mathrm{n}$ & $\%$ & $\mathrm{n}$ & $\%$ & $\mathrm{n}$ & $\%$ & $\mathrm{n}$ & $\%$ & $\mathrm{n}$ & $\%$ & $\mathrm{n}$ & $\%$ \\
\hline Man & 115 & 79,86 & 60 & 88,23 & 96 & 81,35 & 92 & 74,20 & 127 & 75,60 & 490 & 78,9 \\
\hline Woman & 29 & 20,14 & 8 & 11,77 & 22 & 18,65 & 31 & 25,20 & 41 & 24,40 & 131 & 21,1 \\
\hline Total & 144 & 100 & 68 & 100 & 118 & 100 & 123 & 100 & 168 & 100 & 621 & 100 \\
\hline
\end{tabular}

$\mathrm{n}$ : frequency $\%$ : percentage

Table 1 showed the number of reconstructive surgery patients with facial trauma who met the inclusion criteria from 2015 to 2019 were 490 males (78.9\%), higher than that in female of about $131(21.1 \%)$. In 2015 there were 115 males (79.86\%) and 29 females (20.14\%); in $201660(88.23 \%)$ men and $8(11.77 \%)$ women. In 2017 there were $96(81.35 \%)$ men and $22(18.65 \%)$ women. In 2018 there were $92(74.20 \%)$ men and 31 (25.20\%) women. In 2019 there were $127(75.60 \%)$ men and 41(24.40\%) women. These results showed that male sex in maxillofacial fractures is more dominant than female.

\subsubsection{Age}

In this study, ages were differentiated based on the WHO classification, namely infants $0-1$ years, children 2-10 years, adolescents 11-19 years, adults 20-60 years and the elderly over 60 years. Age classification based on WHO, can also be used to determine health risk factors and develop preventive measures. Distribution of facial trauma injury reconstructive surgery patients by age was shown in Table 2

Table 2 Distribution of Patients by Age

\begin{tabular}{|c|c|c|c|c|c|c|c|c|c|c|c|c|}
\hline \multirow[t]{2}{*}{ Age } & \multicolumn{2}{|c|}{2015} & \multicolumn{2}{|c|}{2016} & \multicolumn{2}{|c|}{2017} & \multicolumn{2}{|c|}{2018} & \multicolumn{2}{|l|}{2019} & \multicolumn{2}{|c|}{$2015-2019$} \\
\hline & $\mathrm{n}$ & $\%$ & $\mathrm{n}$ & $\%$ & $\mathrm{n}$ & $\%$ & $\mathrm{n}$ & $\%$ & $\mathrm{n}$ & $\%$ & $\mathrm{n}$ & $\%$ \\
\hline Children & 2 & 1,30 & 2 & 2,95 & 2 & 1,69 & 4 & 3,25 & 3 & 1,78 & 13 & 2,19 \\
\hline Teenager & 32 & 22,32 & 17 & 25,00 & 26 & 22,05 & 18 & 14,63 & 22 & 13,10 & 115 & 19,42 \\
\hline Mature & 110 & 76,38 & 49 & 72,05 & 86 & 72,88 & 99 & 80,48 & 139 & 82,76 & 483 & 76,91 \\
\hline Elderly & 0 & 0,00 & 0 & 0,00 & 4 & 3,38 & 2 & 1,64 & 4 & 2,36 & 10 & 1,48 \\
\hline Total & 144 & 100 & 68 & 100 & 118 & 100 & 123 & 100 & 168 & 100 & 621 & 100 \\
\hline
\end{tabular}

$\mathrm{n}=$ frequency,$\%=$ percentage

Table 2 showed that the age of maxillofacial fracture patients from 2015 to 2019 were $76.91 \%$ or 483 adults, followed by $19.42 \%$ or 115 adolescents, $2.19 \%$ or 13 children and $1.48 \%$ or 10 elderlies. Based on this data, it is assumed that the highest incident of maxillofacial fracture in adult age was due to that the adult age is a productive age with high mobility especially using motorcycle. This is in line with Kraus et.al. (2003) who stated that this age group has the highest traffic accidents, so it is possible that this age is more susceptible to maxillofacial trauma.

Similar study based on age in maxillofacial fracture by Kesuma and Bangun (2009) in Eben E Manalu 
(2018) conducted at RSCM Jakarta, found that the average age of maxillofacial trauma was $27.5 \pm 11.5$ years. The data collected at the Reconstructive and Aesthetic Plastic Surgery KSM Reconstructive and Aesthetic Plastic Surgery, Faculty of Medicine, Airlangga University, Surabaya showed that adults age was the most people, of 483 adults (76.91\%) experienced maxillofacial fracture since this adult age has the highest mobility

\subsubsection{Patient History}

Patient data based on injury history from diagnosis of maxillofacial fracture based on fracture location in one facial area or all facial areas at Dr. Soetomo General Hospital, Surabaya and KSM Reconstructive and Aesthetic Plastic Surgery Airlangga University, Surabaya from 2015 to 2019 was shown in Table 3

Table 3 Distribution of patients by diagnosis of a single facial fracture

\begin{tabular}{|l|l|l|l|l|l|l|l|l|l|l|l|l|l|}
\hline \multirow{2}{*}{ Diagnosis Facial Fracture } & \multicolumn{2}{|l|}{2015} & \multicolumn{2}{l}{2016} & \multicolumn{2}{l|}{2017} & \multicolumn{2}{l|}{2018} & \multicolumn{2}{l|}{2019} & \multicolumn{2}{l|}{$2015-2019$} \\
\cline { 2 - 15 } & $\mathrm{n}$ & $\%$ & $\mathrm{n}$ & $\%$ & $\mathrm{n}$ & $\%$ & $\mathrm{n}$ & $\%$ & $\mathrm{n}$ & $\%$ & $\mathrm{n}$ & $\%$ \\
\hline Frontal/Orbital & 3 & 2,08 & 5 & 7,35 & 1 & 0,84 & 1 & 0,81 & 4 & 2,38 & 12 & 1,93 \\
\hline Parietal & 3 & 2,08 & 3 & 4,41 & 12 & 22,88 & 29 & 23,57 & 33 & 28,57 & 150 & 24,15 \\
\hline Nasal & 0 & 0 & 0 & 0 & 0 & 0 & 5 & 4,06 & 6 & 3,57 & 21 & 3,38 \\
\hline Lacrimal & 25 & 17,36 & 25 & 36,78 & 15 & 12,71 & 9 & 7,31 & 7 & 4,16 & 29 & 4,68 \\
\hline Zigomatic & 29 & 31,25 & 1 & 1,47 & 13 & 12,71 & 21 & 17,07 & 28 & 16,66 & 114 & 18,36 \\
\hline Ethmoid & 3 & 2,08 & 5 & 7,35 & 1 & 0,84 & 1 & 0,81 & 4 & 2,38 & 12 & 1,93 \\
\hline Maxilla & 39 & 34,72 & 4 & 5,58 & 43 & 41,52 & 21 & 18,70 & 28 & 30,35 & 175 & 28,18 \\
\hline Mandibula & 12 & 8,33 & 24 & 35,29 & 12 & 12,71 & 29 & 17,88 & 20 & 11,90 & 102 & 16,42 \\
\hline & & & & & & & & & & & & \\
\hline Unclear & 1 & 1,38 & 0 & 0 & 3 & 4,22 & 1 & 0,81 & 1 & 1,18 & 6 & 0,97 \\
\hline & & & & & & & & & & & 621 & 100 \\
\hline
\end{tabular}

Table 4 Distribution of patients by classification of fracture diagnosis

\begin{tabular}{|c|c|c|c|c|c|c|c|c|c|c|c|c|}
\hline \multirow{2}{*}{$\begin{array}{l}\text { Diagnosis of Facial } \\
\text { Fracture }\end{array}$} & \multicolumn{2}{|c|}{2015} & \multicolumn{2}{|c|}{2016} & \multicolumn{2}{|c|}{2017} & \multicolumn{2}{|c|}{2018} & \multicolumn{2}{|c|}{2019} & \multicolumn{2}{|c|}{$2015-2019$} \\
\hline & $\mathrm{n}$ & $\%$ & $\mathrm{n}$ & $\%$ & $\mathrm{n}$ & $\%$ & $\mathrm{n}$ & $\%$ & $\mathrm{n}$ & $\%$ & $\mathrm{n}$ & $\%$ \\
\hline Single & 47 & 33,10 & 10 & 14,93 & 42 & 35,29 & 44 & 35,48 & 64 & 37,87 & 207 & 33,34 \\
\hline 2 area & 59 & 41,55 & 31 & 46,27 & 38 & 31,93 & 34 & 27,42 & 54 & 31,95 & 216 & 34,78 \\
\hline Panfacial & 36 & 25,35 & 26 & 38,80 & 39 & 32,77 & 46 & 37,10 & 51 & 30,18 & 198 & 31,88 \\
\hline Total & 142 & 100 & 67 & 100 & 119 & 100 & 124 & 100 & 169 & 100 & 621 & 100 \\
\hline
\end{tabular}

$\mathrm{n}=$ frequency, $\%=$ percentage

Table 3 showed the injury history of patients who were not infected or infected after surgery and had administrated ceftriaxone antibiotics and the combination of ceftriaxone, metronidazole in Maxillofacial fractures. It was shown that the highest number of injury obtained from patients which met the inclusion criteria was in maxilla bone, of about 175 patients $(28.18 \%)$, followed by parietal 150 patients $(24.15 \%)$, zygomatic 114patients $(18.36 \%)$, mandible 102 patients $(16.42 \%)$, orbital, nasal, lacrimal, ethmoid and patients with a diagnosis of panfacial type facial fracture, were about 198 patients $(31.88 \%)$.

The most common etiology of facial fractures are motorcycle accidents, violence, and work accidents (Tahereh et al., 2015). Several recent studies conducted at some hospitals trauma unit in several countries showed that the incidence of maxillary fractures was more associated with mandibular fractures. Other data reported from trauma center level, showed that among 663 patients with facial bone fractures, only $25.5 \%$ were maxillary fractures (Eben, 2018).

Maxillary fracture is a form of trauma to the face that often caused by mainly motor vehicle accidents. Treatment of maxillary fractures not only considers functional but also aesthetic issues. The fracture pattern that occurs does not always follow the theoretical Le Fort I, II, and III pattern, but is more often a combination of these classifications. There are some basic things about maxillary fractures i.e: 1. For maxillary fractures to occur, whether Le Fort I, II, or III, the pterygoid process must be disrupted; 2 . The presence of mobility and malocclusion on physical examination is a hallmark of maxillary fracture although not all maxillary fractures cause mobility; 3. Radiological examination, either plain X-ray or CT scan is needed to confirm the diagnosis, but CT scan is the main choice; 4. Maxillary fractures generally have a fairly good prognosis if the treatment is carried out quickly and appropriately, but complications which may lead to disability or death could arise, if it is not handled properly; 5. Maxillary fractures in children are different from adults because of a more prominent growth and development in children. The maxillary structure has a sinus cavity, which produces secretions to moisten the cavity, trapping dust and bacteria, so that in the case of maxillofacial fractures, it is a good medium for bacteria to grow and increase the risk of infection. 
3.2 The Relationship Between Ceftriaxone Antibiotics and Ceftriaxone, Metronidazole Combination with Postoperative Infections of Maxillofacial Fractures

The data obtained were tested by chi-square. The results showed, the relationship between the administration of ceftriaxone antibiotics and the combination of ceftriaxone, metronidazole and infection in maxillofacial fractures at KSM Reconstructive and Aesthetic Plastic Surgery Dr. Soetomo General Hospital, Surabaya in 2015 until 2019 was shown in Table 5

Table 5 The Relationship Between Administration of Ceftriaxone Antibiotics, Ceftriaxone, Metronidazole Combination and Infection after Surgery on Maxillofacial Fractures

\begin{tabular}{|c|c|c|c|c|c|c|c|}
\hline \multirow{3}{*}{ Antibiotic } & \multicolumn{7}{|c|}{ Infections of Maxillofacial Fractures } \\
\hline & \multicolumn{2}{|c|}{ Not Infected } & \multicolumn{2}{|c|}{ Infected } & \multirow{2}{*}{$\begin{array}{l}\text { Chi Square } \\
\text { Acount }\end{array}$} & \multirow{2}{*}{$\begin{array}{l}\text { Chi Square } \\
\text { Table }\end{array}$} & \multirow{2}{*}{$\begin{array}{l}\text { Significance } \\
\text { (a) }\end{array}$} \\
\hline & $\mathrm{n}$ & $\%$ & $\mathrm{n}$ & $\%$ & & & \\
\hline $\begin{array}{l}\text { Ceftriaxone and Metroni- } \\
\text { dazole Combination }\end{array}$ & \multirow[t]{2}{*}{611} & \multirow[t]{2}{*}{98,39} & 4 & 0,64 & 0,0483 & 0.016 & 0,000 \\
\hline Ceftriaxone & & & 6 & 0,97 & 11,477 & 3.825 & 0,000 \\
\hline Total & 611 & 98,39 & 10 & 1,61 & 11,526 & 3,841 & 0,000 \\
\hline
\end{tabular}

$\mathrm{n}=$ frequency, $\%=$ percentage

Table 5. showed that the relationship between administration of ceftriaxone antibiotics and the combination of ceftriaxone, metronidazole, to infection after surgery in maxillofacial fractures at KSM Reconstructive and Aesthetic Plastic Surgery Dr. Soetomo General Hospital, Surabaya in 2015 to 2019, was significant, since the resulted $p$-value is $0.000(p<0.05)$. The value of the Chi-Square test is 11.526 ; on the other hand the value of the chi-square table $(\mathrm{T}$ table) for $\mathrm{df}$ (degrees of freedom $)=1$ at a significance of 0.05 is 3.841 . Since the calculated chi square value $>$ chi square table value, it can be concluded that null hypothesis is rejected and the result is accepted, thus the results of this study indicated that there was a significant relationship between the administration of the antibiotic ceftriaxone and the combination of ceftriaxone, metronidazole, to infection after surgery for maxillofacial fractures.

Table 5. also showed that from 621 medical records of patients who received antibiotics or $100 \%$; $98.39 \%$ of those had no infection and $1.61 \%$ of those develop an infection. The results of this study was supported by Andayani and Riswaka (2005) who stated that $100 \%$ of patients at the PKU Muhammadiyah Hospital in Yogyakarta, received prophylactic antibiotics followed by the administration of therapeutic antibiotics. Furthermore Gondo (2007) stated that the combined use of antibiotics has several advantages such as reducing resistance to antibiotics because the use of synergistic combinations of antibiotics can increase the ability of antibiotics to kill germs. In addition, the use of antibiotics in combination can reduce the toxic effects of drugs because the lower the dose of each type of antibiotic given, the lower the toxicity. In a study at Bethesda Hospital with 30 cases of acute appendicitis surgery, given a combination of ceftriaxone and metronidazole antibiotics, the infection rate was low (Sander, 2015). The use of single therapy antibiotics in this case was caused by the patient's ability to receive antibiotics orally. Most patients who receive antibiotics intravenously can safely be switched to oral therapy 24 hours later if their clinical condition improves, such as an improvement in signs and symptoms of infection (Anonymous, 2009).

The results of statistical analysis with the hypothesis that the risk of infection after facial fracture reconstruction surgery is lower in the administration of a combination of antibiotics ceftriaxone and metronidazole compared to the administration of a single antibiotic ceftriaxone at the Reconstructive and Aesthetic Plastic Surgery KSM Dr. Soetomo General Hospital, Surabaya in 2015, 2016, 2018, 2019; the null hypothesis test was accepted $(p<0.05)$, while in 2017 the null hypothesis test was rejected $(p>0.05)$. These indicate that the research hypothesis is statistically significant.

\subsection{Estimation of the Curve of the Relationship Between Ceftriaxone Antibiotics and the Combination of Ceftriaxone, Metronidazole and Postoperative Infection of Maxillofacial Fractures}

Estimation of the curve of the relationship between the independent variables, namely the administration of ceftriaxone antibiotics and the combination of ceftriaxone, metronidazole with the dependent variable, namely infection after surgery for maxillofacial fractures: linear, exponential or quadratic as shown in Table 6.

Table 6 Estimation of the Curve of the Relationship Between Ceftriaxone Antibiotics and the Combination of Ceftriaxone, Metronidazole and Postoperative Infection of Maxillofacial Fractures

\begin{tabular}{|l|l|c|c|c|c|c|c|c|}
\hline \multirow{2}{*}{ Equation } & \multicolumn{4}{|c|}{ Model Summary } & \multicolumn{3}{c|}{ Estimation Parameter } \\
\cline { 2 - 10 } & R Square & F & df1 & df2 & Sig. & Constant & b1 & b2 \\
\hline Linear & .019 & 11.706 & 1 & 619 & .001 & 1.931 & .034 & \\
\hline Square &. & & & &. & 1.984 & .000 & .000 \\
\hline Exponential & .019 & 11.706 & 1 & 619 & .001 & 1.907 & .024 & \\
\hline
\end{tabular}

Table 6. showed that the $\mathrm{p}$ value on Estimation of linear and exponential curves was lower than 0.05 ( $\mathrm{p}<$ 
0.05). Thus, the estimation of the curve of the relationship between the independent variables, namely the administration of the antibiotic ceftriaxone and the combination of ceftriaxone, metronidazole with the dependent variable, is linear and exponential to postoperative infection of maxillofacial fractures and from the results of the model's description analysis was exponential (Curve model like Figure 1)

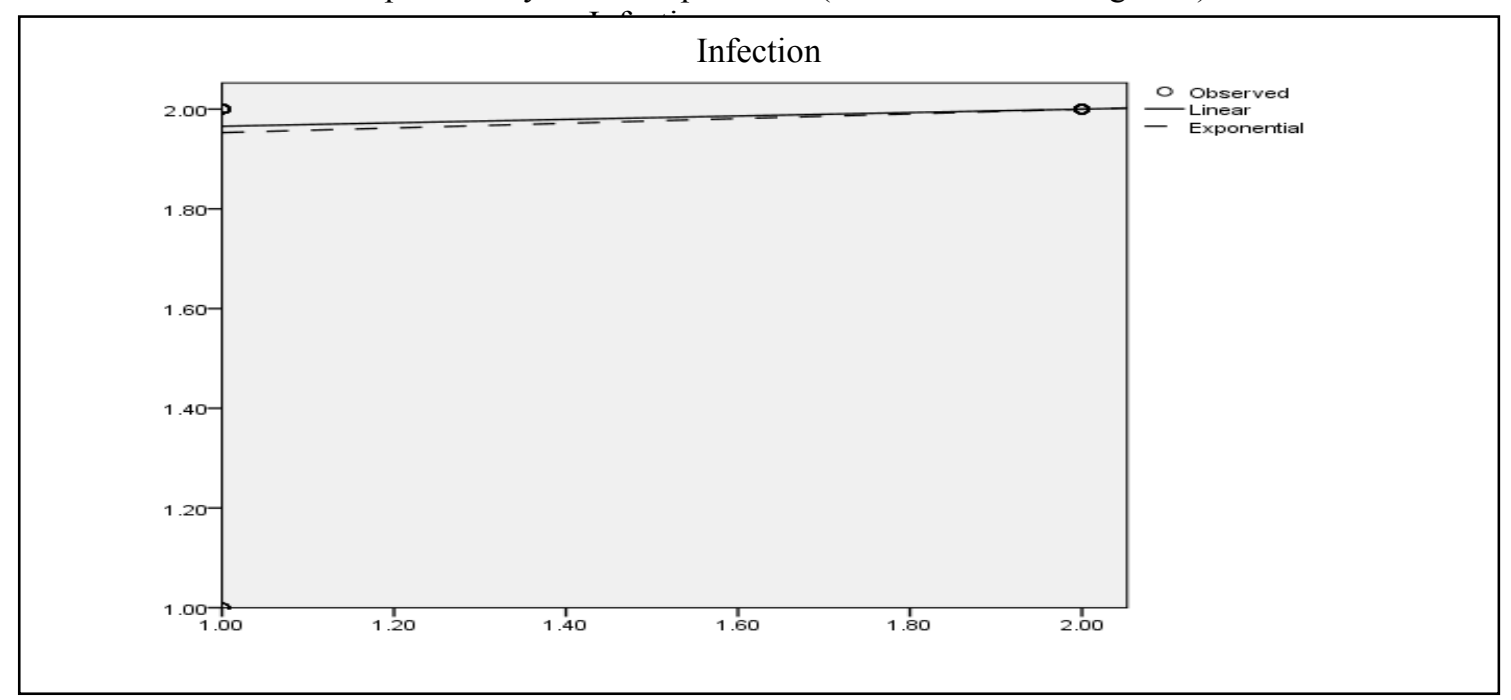

Figure 1. The Curve Model of the Relationship Between the Administration of Ceftriaxone Antibiotics And the Combination of Ceftriaxone, Metronidazole and Infection after Surgery in Maxillofacial Fractures

\section{Conclusion}

The incidence of post-operative infection of facial fractures was higher in the administration of single ceftriaxone antibiotics compared to the combination of ceftriaxone, metronidazole at KSM Reconstructive and Aesthetic Plastic Surgery, Dr. Soetomo General Hospital, Surabaya from 2015 until 2019.

\section{Suggestion}

It is recommended to use combination of antibiotic ceftriaxone and metronidazole therapy in cases of maxillofacial fracture surgery compared to single antibiotics.

\section{References}

Andayani Tri Murti dan Riswaka Sudjaswani. 2005. Evaluasi Ekonomi Penggunaan Antibiotika pada Kasus Bedah Sesar di Rumah Sakit PKU Muhammadiyah Yogyakarta. Majalah Farmasi Indonesia. 16 (2):70-75

Anderson, D., Kaye, K. and Chen, L. (2009) 'Clinical and financial outcomes due to methicillin resistant Staphylococcus aureus surgical site infection: a multi - center matched outcomes study’, PLoS One, 4(12), p. e8305.

Anderson, T. and Alpert, B. (1992) 'Experience with rigid fixation of mandibular fractures and immediate function', J Oral Maxillofac Surg, 50, pp. 555-60.

Anonim, 2009. Antibiotic Policy for Adult Patients: Epirical Antimicrobial Therapy for Common Infections and Surgical Prophylaxis. Pennine Acute Hospital NHS Trust Drugs and The Therapeutics Committee

Azari, A. F. and Bell, R. B. (2016) Infection in the Craniomaxillofacial Trauma Patient, Head, Neck, and Orofacial Infections. Elsevier Inc. doi: 10.1016/b978-0-323-28945-0.00024-7.

Bakardjiev, A. and Pechalova, P. (2007) 'Maxillofacial fractures in Southern Bulgaria - a retrospective study of 1706 cases', J Craniomaxillofac Surg, 35(3), pp. 147-150.

Berríos-Torres, S. et al. (2017) 'Healthcare Infection Control Practices Advisory Committee. Centers for Disease Control and Prevention Guideline for the Prevention of Surgical Site Infection, 2017', JAMA Srug, 152(8), pp. 784-91.

Buhairan, B., Hind, D. and Hutchinson, A. (2008) 'Antibiotik prophylaxis for wound infections in total joint arthroplasty: a systematic review', J Bone Joint Surg Br, 90(7), pp. 915-9.

Burton, J. and Kuehl, K. (2013) 'Facial Trauma', in Adams, J. (ed.) Emergency Medicine. 2nd edn. Philadelphia: Elsevier Inc., pp. 661-72.

Chandrasekaran, B. and Fernandes, S. (2020) 'Since January 2020 Elsevier has created a COVID-19 resource centre with free information in English and Mandarin on the novel coronavirus. The COVID-19 resource centre is hosted on Elsevier Connect, the company' s public news and information website . ', Diabetes 
Metab Syndr., 14(4)(January), pp. 337-339.

Chole, R. and Yee, J. (1987) 'Antibiotik prophylaxis for facial fractures: a prospective, randomized clinical trial', Arch Otolaryngol Head Neck Surg, 113, pp. 1005-57.

Cottrell, D. A. et al. (2017) 'Surgical Correction of Maxillofacial Skeletal Deformities', Journal of Oral and Maxillofacial Surgery, 75(8), pp. e94-e125. doi: 10.1016/j.joms.2017.04.025.

Crader, M. and Varacallo, M. (2021) 'Preoperative Antibiotik Prophylaxis', StatPearls.

Doerr, T. (2015) 'Evidence-based facial fracture management', Facial Plast Surg Clin North Am, 23(3), pp. $335-45$.

Eben E Manalu (2018) Hubungan antara Facial Injury Severity Scale (FISS) dengan kejadian cidera kepala dan cidera leher di RSUP H Adam Malik Medan. Departemen Ilmu Bedah Fakultas Kedokteran Universitas Sumatra Utara, Tesis

Ellis, E. 3rd and Kittidumkerng, W. (1996) 'Analysis of treatment for isolated zygomaticomaxillary complex fractures', J Oral Maxillofac Surg, 54(4), pp. 386-400.

Esmaeelinejad, M. (2018) 'Maxillofacial Fractures: From Diagnosis to Treatment', IntechOpen. Available at: doi: 10.5772/intechopen.76166.

Fujita, S. (2007) 'Fujita, S. (2007). Randomized, Multicenter Trial of Antibiotik Prophylaxis in Elective Colorectal Surgery. Archives of Surgery, 142(7), 657. doi:10.1001/archsurg.142.7.657', Archives of Surgery, 142(7), p. 657.

Gassner, R., Tuli, T. and Hachl, O. (2003) 'Cranio-maxillofacial trauma: a 10 year review of 9,543 cases with 21,067 injuries’, J Craniomaxillofac Surg, pp. 51-61.

GG, H. (1992) 'Microsurgical repair of the parotid duct.', Microsurgery, 13, pp. 243-6.

Gómez Roselló, E. and Quiles Granado, AM Artajona Garcia, M. (2020) 'Facial fractures: classification and highlights for a useful report', Insights Imaging, 11(49). Available at: https://doi.org/10.1186/s13244-02000847-w.

Gondo, Harry K. 2007. Penggunaan Antibitika pada Kehamilan. Wijaya Kusuma. 1 (1):57-62.

Gunawan, Sulistia G., Rianto Setiabudy Nafrialdi, Elysabeth, dkk. 2008. Farmakologi dan Terapi. Edisi ke-5. Departemen Farmakologi dan Terapeutik Fakultas Kedokteran Universitas Indonesia, Jakarta

Gruss, J. et al. (1990) 'The importance of the zygomatic arch in complex midfacial fracture repair and correction of posttraumatic orbitozygomatic deformities', Plast Reconstr Surg, 85(6), pp. 878-890.

Hom, D. (2009) 'Essential tissue healing of the face and neck', in Shelton, C. (ed.) People's Medical House.

Horan, T., Gaynes, R. and Martone, W. (1992) 'CDC definitions of nosocomial surgical site infections, 1992: a modification of CDC definitions of surgical wound infections', Infection Control and Hospital Epidemiology, 13(606-8).

Ignacio, J., Escobar, S. and Fernández, A. (2006) ‘Antibiotik prophylaxis in Oral and Maxillofacial Surgery’, pp. 292-296.

Jose, A. et al. (2016) 'Management of maxillofacial trauma in emergency: An update of challenges and controversies', J Emerg Trauma Shock, 9(2), pp. 73-80.

Kellman, R. (2021) 'Maxillofacial Trauma', in Flint, P. et al. (eds) Cummings Otolaryngology: Head and Neck Surgery. 7th edn. Philadelphia: Elsevier Inc., pp. 286-310.e3.

Kraft, A., Abermann, E. and Stigler, R. (2012) 'Craniomaxillofacial trauma: synopsis of 14,654 cases with 35,129 injuries in 15 years', Craniomaxillofac Trauma Reconstr, 5(1), pp. 41-50.

Kraus et al., 2003. Facial Trauma and the Risk of Intracranial Injury in Motorcycle Riders. Annals of Emergency Medicine 41 (1), p18-26.

Kühne, C. et al. (2007) 'Epidemiologie und Behandlungsmanagement bei Schockraum patienten mit Gesichtsschädelverletzungen', Mund Kiefer GesichtsChir, 11(4), pp. 201-8.

Lee, H. (2009) 'Interpersonal violence and facial fractures', J Oral Maxillofac Surg, 67(9), pp. 1878-1883.

Ludi, E. et al. (2016) 'Do radiologists and surgeons speak the same language? A retrospective review of facial trauma', AJR Am J Roentgenol, 207(5), pp. 1070-76.

Merkow, R., Ju, M. and Chung, J. (2015) 'Underlying reasons associated with hospital readmission following surgery in the United States', JAMA, 313(5), pp. 483-495.

Mottini, M., Wolf, R. and Soong, P. (2014) 'The role of postoperative antibiotiks in facial fractures: comparing the efficacy of a 1-day versus a prolonged regimen', J Trauma Acute Care Surg, 76, pp. 720-24.

Mph, S. R. T. et al. (2021) 'Reducing surgical site infections after hysterectomy: metronidazole plus cefazolin compared with cephalosporin\&nbsp;alone', The American Journal of Obstetrics \& Gynecology. Elsevier Inc., 217(2), pp. 187.e1-187.e11. doi: 10.1016/j.ajog.2017.03.019.

National Collaborating Centre for Women's and Children's Health (2008) Surgical Site Infection: Prevention and Treatment of Surgical Site Infection, London: RCOG Press. Available at: https://www.ncbi.nlm.nih.gov/books/NBK53731/.

Nicolau, D. et al. (1995) 'Cephalosporin-metronidazole combinations in the management of intra-abdominal 
infections', Diagn Microbiol Infect Dis, 22(1-2), pp. 189-94.

Ochs, M., Tucker, M. and Bauer, R. (2019) 'Management of Facial Fractures', in Hupp, J., Eliss, E., and Tucker, M. (eds) Contemporary Oral and Maxillofacial Surgeru. 7th edn. Philadelphia: Elsevier Inc, pp. 519-45.

Pisculli, M., Barker, F. and Farrell, C. (201AD) 'Postoperative Infections of the Head and Brain', in Winn, H. (ed.) Youmans and Winn Neurological Surgery. 7th edn. Philadelphia: Elsevier Inc., pp. 319-330.e3.

Setiawan, Didik dan Haefa Akhmad Baraba. 2007. Pola Penggunaan Antibiotika Profilaksis pada Pasien Bedah Caesar di Rumah Sakit Umum Daerah Purbalingga Tahun 2007. Proseeding Kongres Ilmiah ISFI XVI 2008.

Tan, T. et al. (2017) 'Should Preoperative Antibiotiks Be Tailored According to Patient's Comorbidities and Susceptibility to Organisms?', J Arthroplasty, 32(4), pp. 1089-94.e3.

Tarchini, G., Liau, K. and Solomkin, J. (2017) 'Antimicrobial Stewardship in Surgery: Challenges and Opportunities', Clin Infect Dis, 15(64(Suppl 2)), pp. S112-S114.

Treem, W. (2001) 'New evidence on unexplained early infant crying: its origins, nature and management.' Johnson \& Johnson Pediatric Institute.

Varacallo, M. et al. (2018) 'Cost Determinants in the 90-Day Management of Isolated Ankle Fractures at a Large Urban Academic Hospital', J Orthop Trauma, 32(7), pp. 338-343.

W-Dah, A. et al. (2011) 'Timing of preoperative antibiotiks for knee arthroplasties: Improving the routines in Sweden', Patient Saf Surg, 5, p. 22.

Zabagio, M. and Sharman, T. (2020) Postoperative Wound Infection, StatPearls. Florida: StatPearls Publishing.

Lawrence, S. et al. (2001). Persistence of Web References in Scientific Research. Computer. 34, $26-31$. doi:10.1109/2.901164, http://dx.doi.org/10.1109/2.901164

Smith, Joe, (1999), One of Volvo's core values. [Online] Available: http://www.volvo.com/environment/index.htm (July 7, 1999)

Strunk, W., Jr., \& White, E. B. (1979). The elements of style. (3rd ed.). New York: Macmillan, (Chapter 4).

Van der Geer, J., Hanraads, J. A. J., \& Lupton R. A. (2000). The art of writing a scientific article. Journal of Scientific Communications, 163, 51-59 